\title{
Tillage system effect on the epidemic of soybean brown spot
}

\author{
Álvaro M. R. Almeida ${ }^{1}$ Bernhard Hau ${ }^{2}$ - Lilian Amorim ${ }^{3} \cdot$ Armando Bergamin Filho $^{3}$ • \\ Joaquim C. Mariano ${ }^{4}$
}

Received: 7 May 2015 / Accepted: 2 September 2015

(C) Sociedade Brasileira de Fitopatologia 2015

\begin{abstract}
Six field experiments were carried out during the summers of 1997 to 2003 to evaluate disease progress of soybean brown spot caused by Septoria glycines considering two tillage systems, conventional and no-tillage (wheat was cultivated during winter in all plots). Two logistic models were fitted to the disease progress data: (i) a logistic model with constant disease progress rate $r\left[y=1 /\left(1+\left(1 / y_{0}-1\right) \exp (-r t)\right)\right.$, where $y_{0}$ is the initial disease level at time $\left.t=0\right]$ and (ii) a logistic model with an exponentially increasing progress rate $r(t)=r_{0} \mathrm{e}^{b t}\left[y=1 /\left(1+\left(1 / y_{0}-1\right) \exp \left(r_{0} / b\left(1-\mathrm{e}^{b t}\right)\right)\right)\right.$, where $r_{0}$ is the initial progress rate at time $t=0, b$ the rate increasing parameter, and $y_{0}$ again the initial disease level]. The logistic model with constant rate underestimated disease incidence on the first disease assessment in nine out of twelve epidemics. The logistic model with an increasing rate gave a better fit to all disease progress curves $\left(\mathrm{R}^{2}\right.$ between 0.90 and 0.99 ; no pattern in the residuals). According to this model, $y_{0}$ was in most cases (four out of six) significantly smaller in the plots with no-tillage compared with conventional tillage, but no differences were detected in the initial rate parameter $r_{0}$ and the rate increasing parameter $b$ (with one exception). It is proposed that these results are due to higher susceptibility of old leaflets compared with young leaflets, as demonstrated by artificial
\end{abstract}

\section{Section Editor: Harald Scherm}

Álvaro M. R. Almeida

alvaro.almeida@embrapa.br

Embrapa Soja, Caixa Postal 231, 86001-970 Londrina, PR, Brazil

2 Leibniz University Hannover, Herrenhaeuser Str. 2, D-30419 Hannover, Germany

3 USP-ESALQ, Av. Pádua Dias 11, 13418-900 Piracicaba, SP, Brazil

4 COAMO, 87300-000 Campo Mourão, PR, Brazil inoculation: In four laboratory experiments the mean brown spot severity was $16.7 \%$ on old leaflets but only $3.9 \%$ on young leaflets.

Keywords Glycinemax · Septoriaglycines · Disease progress models $\cdot$ Soybean late diseases

\section{Introduction}

Soybean brown spot, caused by Septoria glycines, is a limiting factor in most soybean production regions of the world (Wrather et al. 1997; Almeida et al. 2005). Brown spot often co-occurs with Cercospora kikuchii, and under favorable weather conditions, the two diseases may cause severe defoliation, mainly during the late stages of the crop. Therefore, they are considered part of the late season disease complex (Yorinori 1994).

In Brazil, brown spot has caused several epidemics of varying intensities. Experimental results demonstrated that depending on the time of infection, the disease could induce losses of up to $30 \%$ (Almeida 1980). In 1994, soybean brown spot caused an estimated yield reduction in Brazil of 1.1 million metric tons (Wrather et al. 1997).

Brown spot severity is influenced by temperature and periods of leaf wetness duration (Schuh and Adamowicz 1993). The optimum temperature for disease development is $25^{\circ} \mathrm{C}$ and disease severity increases with leaf wetness duration at least up to $36 \mathrm{~h}$. Although control has been achieved with fungicides, it has been observed that cultivars CTS-40, IAS2, IAS-5, PI 230975, and PI 204332 exhibited less infected leaf area and a longer period to reach $5 \%$ disease severity (Almeida 2001). However, crop management could also be a good approach to help control brown spot. Preliminary studies reported that disease severity was lower in no-tillage system, 
compared with the conventional system (Almeida et al. 1999; Almeida 2003). These results are in agreement with those reported by Tyler et al. (1983) who were the first to report on the effect of tillage system in this pathosystem. Paradoxically, no-tillage results in a substantial amount of crop residue being left on the soil surface that may serve as the inoculum source for brown spot.

In southern parts of Brazil, however, double cropping is commonly adopted by farmers. The winter crop, generally wheat or oats, leaves a layer of residue over the soil surface (approximately $3 \mathrm{t} / \mathrm{ha}$ ) that may obstruct the release of pathogen propagules remaining in soybean debris from the previous season (Almeida 2003).

The epidemiology of soybean brown spot is not completely known, especially in Brazil where the crop is cultivated in large areas ranging from tropical to sub-tropical climates. The objective of this work was to determine the effect of tillage system on key epidemic parameters of brown spot, i.e., initial disease level and disease progress rate.

\section{Material and methods}

\section{Field plots and disease assessment}

Randomized complete block design experiments with two cultivation systems (conventional and no-tillage) and four replications were carried out during the 1997/2003 growing sea-

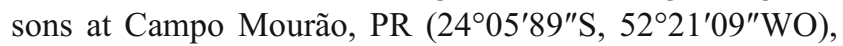
Brazil. Wheat cv. BRS 220 was cultivated during winter in all plots. The plot size was $11 \mathrm{~m} \times 3.5 \mathrm{~m}$ with seven rows of soybean cv. BR-16 (0.5 m inter-rows) with a final density of 16 plants per linear meter. Conventional and no-tillage are defined here as soil preparation systems representing "clean tillage" and "conservation tillage", respectively. In the conventional or clean tillage, the soil surface is essentially free of plant residues due to the sequence of tillage operations. In conventional tillage in this experiment, disk plowing was used as primary tillage, followed by disk harrowing as secondary tillage. Frequently, a third operation with a harrow disk is needed to obtain a smooth seed bed. In the no-tillage or conservation tillage, the soil is left undisturbed. A special planter or drill was adapted with a coulter or seed furrow opener. A narrow soil band was prepared where the seeds and fertilizers were deposited. Nearly $90 \%$ of the soil surface was covered with the previous crop residue.

Soybean sowing dates were: 14 November 1997; 11 November 1998; 27 October 1999; 4 November 2000; 8 November 2001 and 11 November 2002. Daily mean temperature, rainfall and moisture data were recorded from a weather station near the experimental site.

Disease severity assessment was based on the single plant approach. Fifteen plants per plot were randomly evaluated disregarding border rows. From each plant a trifoliate leaf taken from the base, the middle, and the top of the marked plants was evaluated for severity based on a diagrammatic scale (James 1971) at different intervals (3 to 9 days, starting with the appearance of the first symptoms).

\section{Laboratory studies}

An experiment was performed to evaluate the effect of soybean brown spot on the susceptibility of excised soybean leaves (cv. BR-16) with different ages. New (uppermost trifoliate leaflets) and old leaflets were sprayed with a suspension of spores with concentrations among experiments ranging from $10^{5}$ to $10^{6}$ conidia $/ \mathrm{mL}$. The volume applied on each leaflet was $1 \mathrm{~mL}$. A piece of moistened cotton was placed in the petiole cut end. After inoculation the leaflets were incubated in a germination box over moistened filter paper at room temperature $\left(25 \pm 3{ }^{\circ} \mathrm{C}\right)$. Evaluation was performed daily for disease severity based on the percentage of diseased leaf area

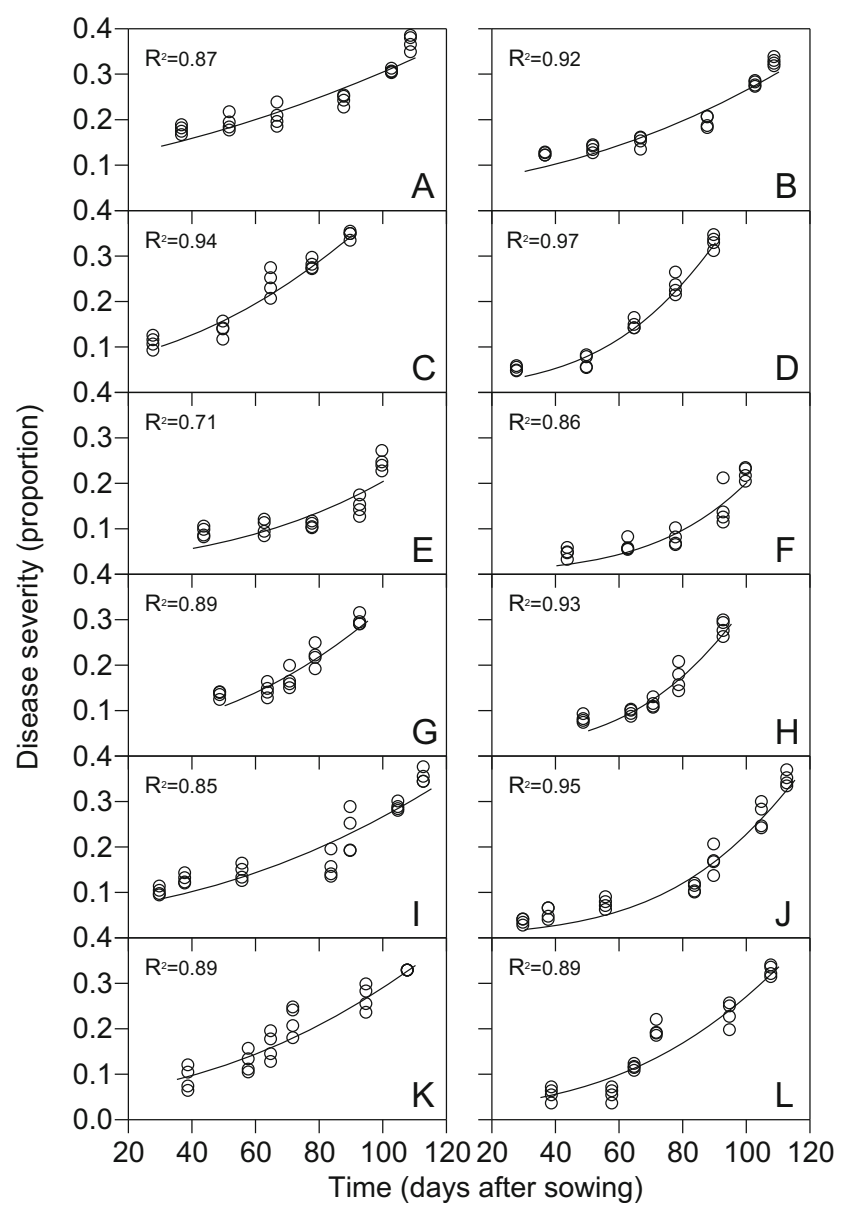

Fig. 1 Observed brown spot disease progress curves (measured as disease severity at four points) under conventional tillage ( $a, c, e, g, i$, $k$ ) and no-tillage $(b, d, f, h, j, l)$ systems during seasons $1997 / 98(a, b)$, 1998/99 (c,d), 1999/00 (e,f), 2000/01 $(g, h), 2001 / 02(i, j)$ and 2002/03 $(k, l)$. Solid lines correspond to the fitted logistic functions with constant rate 


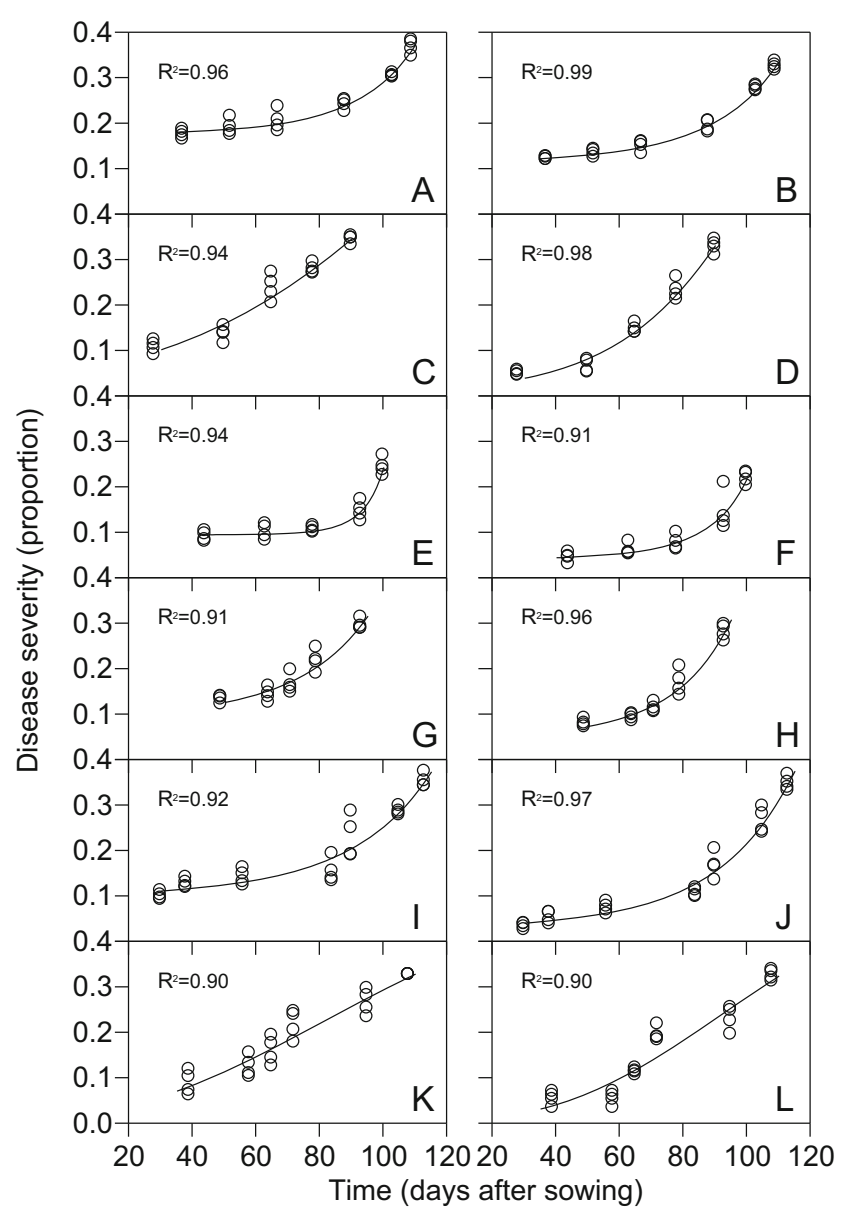

Fig. 2 Observed brown spot disease progress curves (measured as disease severity at four points) under conventional tillage ( $a, c, e, g, i$, $k$ ) and no-tillage $(b, d, f, h, j, l)$ systems during seasons 1997/98 $(a, b)$, 1998/99 (c, d), 1999/00 $(e, f), 2000 / 01(g, h), 2001 / 02(i, j)$ and 2002/03 $(k, l)$. Solid lines correspond to the fitted logistic functions with exponentially increasing rate

for 15-19 days. The experimental design was completely randomized with two treatments (new and old leaflets) and ten replications. The experiment was repeated four times.

\section{Data analysis}

Two logistic disease progress models were fitted to the field data. A logistic model with constant rate parameter $r[y=1 /$ $\left(1+\left(1 / y_{0}-1\right) \exp (-r t)\right)$, where $y_{0}$ is the initial disease level at time $t=0]$ and a logistic model with exponentially increasing progress rate $r(t)=r_{0} \mathrm{e}^{b t}\left[y=1 /\left(1+\left(1 / y_{0}-1\right) \exp \left(r_{0} / b\left(1-\mathrm{e}^{b t}\right)\right)\right)\right.$, where $r_{0}$ is the initial progress rate at time $t=0, b$ a rate increasing parameter, and $y_{0}$ again the initial disease level]. The corresponding differential equations are $\mathrm{d} y / \mathrm{d} t=r \quad y(1-y)$ and $\mathrm{d} y / \mathrm{d} t=r_{0} \mathrm{e}^{b t} y(1-y)$, respectively, showing that in the latter case, the rate increases exponentially starting from the initial rate $r_{0}$ at time $t=0$ and, therefore, the speed of disease progress increases exponentially with time $t$. A similar approach was used by Bergamin et al. (1998) who fitted an exponential model with a linearly increasing rate to progress data of Fatal yellowing of oil palms. The suitability of the models to describe the disease progress curves was determined by the coefficients of determination $\left(\mathrm{R}^{2}\right)$ and the plot of standardized residuals versus predicted values (Campbell and Madden 1990; Madden et al. 2007). When the rate increasing parameter $b$ was not significantly different from 0 , the logistic model with constant rate was adequate to describe the disease progression. The parameter values estimated by fitting the functions to the progress data in the two tillage systems were compared by t-test.

The disease severity data of the laboratory studies were transformed with square root transformation $(y+0.5)^{1 / 2}$. The results of the two leaflet ages were compared by t-test. All statistical analyses were performed using Statistica v.6 (Statsoft).

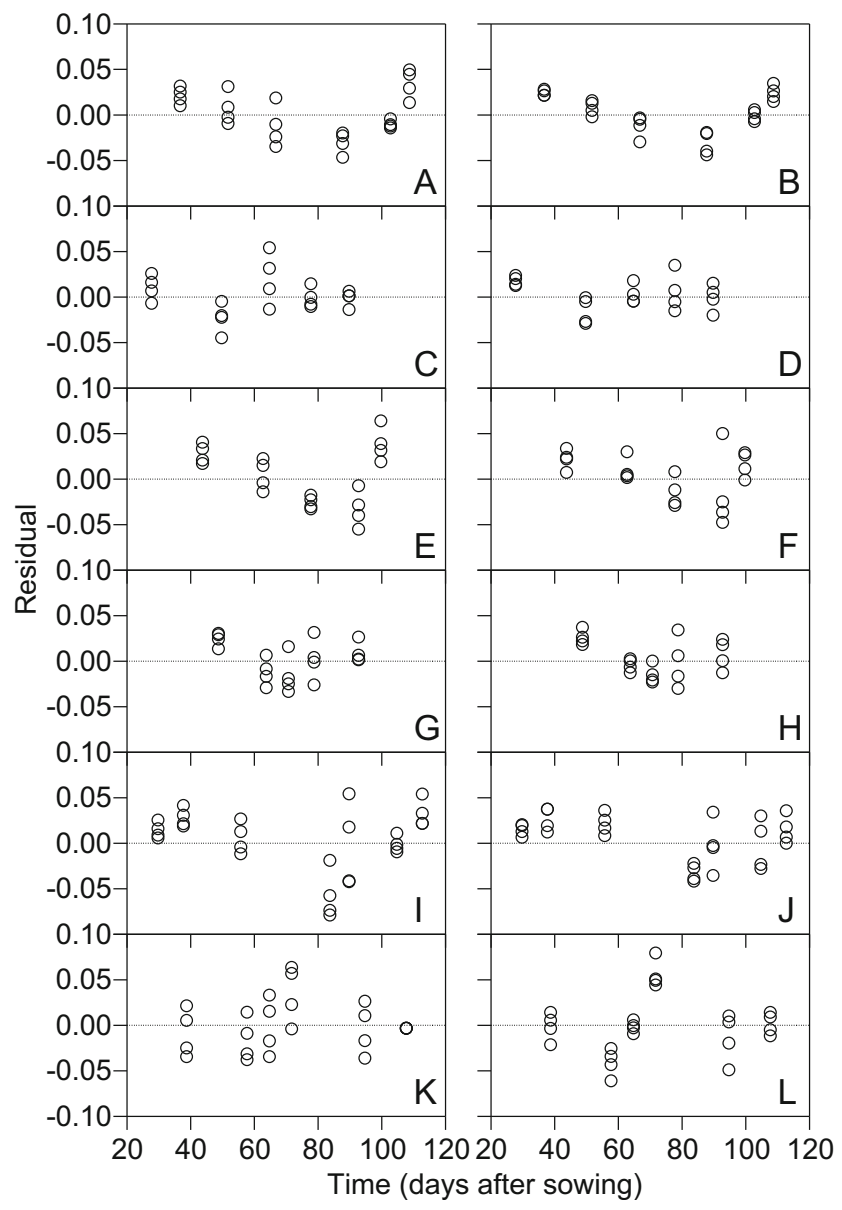

Fig. 3 Residuals from fitting the logistic model with constant rate to brown spot disease progress curves under conventional tillage $(a, c, e$, $g, i, k)$ and no-tillage $(b, d, f, h, j, l)$ systems during seasons $1997 / 98(a, b)$, 1998/99 $(c, d), 1999 / 00(e, f), 2000 / 01(g, h), 2001 / 02(i, j)$ and 2002/03 $(k, l)$ 


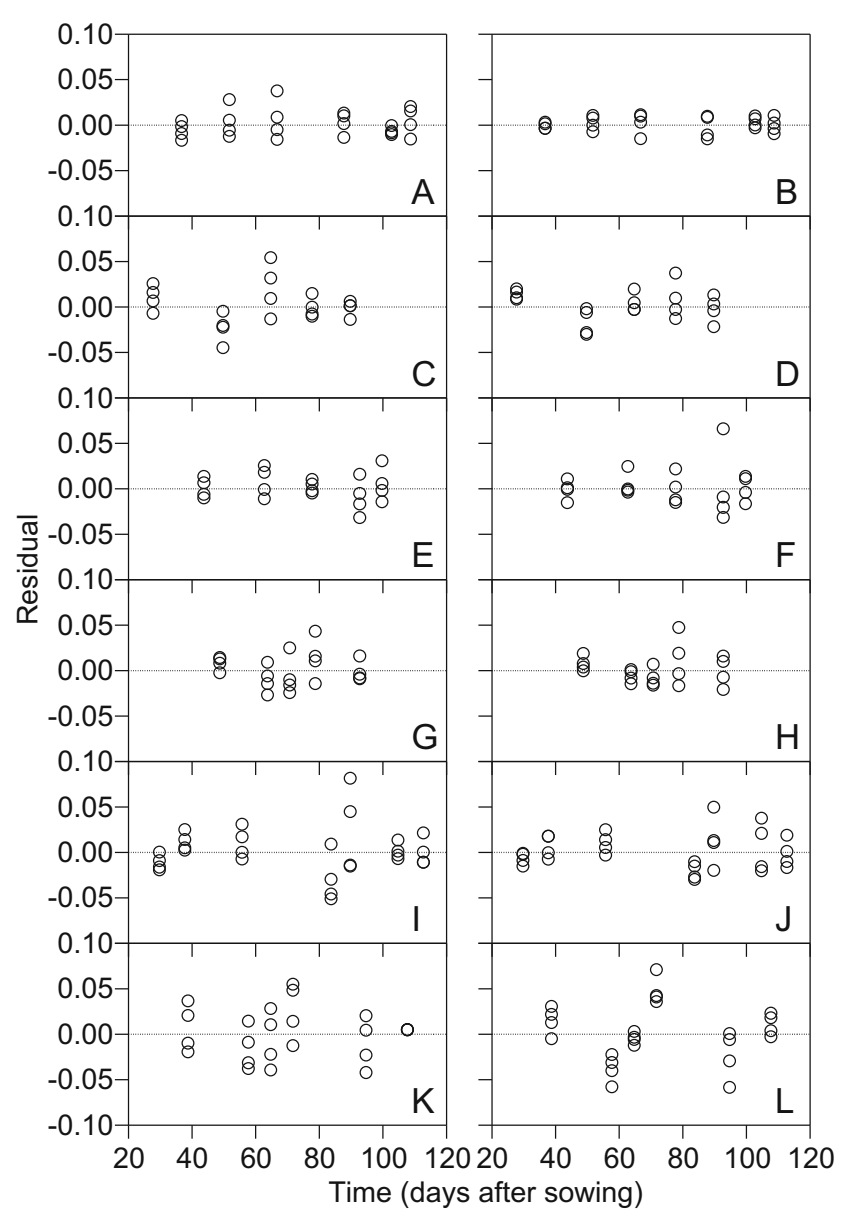

Fig. 4 Residuals from fitting the logistic model with exponentially increasing rate to brown spot disease progress curves under conventional tillage $(a, c, e, g, i, k)$ and no-tillage $(b, d, f, h, j, l)$ systems during seasons 1997/98 (a,b), 1998/99 (c, d), 1999/00 (e, f), 2000/01 $(g, h), 2001 / 02(i, j)$ and 2002/03 $(k, l)$

\section{Results}

In all years, field symptoms of brown spot were the first to be noticed compared with other soybean diseases. Dark and almost circular lesions started to appear first on primary leaves, followed by middle leaves and later in the season, top leaves. The disease occurred every year starting 30-50 days after sowing and increased along the season (Figs. 1 and 2).

The logistic model underestimated the initially observed disease level in nine out of twelve epidemics (Fig. 1). In almost all seasons, the disease incidence between the first and the third assessments increased only slightly. An abrupt change in incidence occurred from mid-season, when the curves exhibited a sharper slope. The logistic model with an exponentially increasing rate (Fig. 2) gave a better fit to all disease progress curves compared with the model with constant rate (Fig. 1). Specifically, the low increase of the progress curves in the first three assessments was much better described by this model. A comparison of the distribution of the residuals (Figs. 3 and 4) clearly shows that only the logistic function with increasing rate resulted in a random scatter. Thus, the model with increasing rate was used in the comparison of the tillage systems.

According to this model, the initial disease level $\left(y_{0}\right)$ of the epidemics was in most cases (four out of six) significantly smaller in the plots with no-tillage (Table 1) compared with conventional tillage, whereas in the other two cases $y_{0}$ did not differ significantly. No significant differences were detected in the initial progress rate $\left(r_{0}\right)$ and the rate increasing parameter $b$ (except in 1999/00) (Table 1). In the 1999/00 season, the disease incidence stayed nearly constant during the first three assessments, especially for conventional tillage. This is
Table 1 Initial disease level $\left(y_{0}\right)$, initial progress rate $\left(r_{0}\right)$, parameter of rate increase $(b)$ and the corresponding standard errors, estimated by a logistic model with an exponentially increasing rate $y=1 /\left(1+\left(1 / y_{0}-1\right) \exp \left(r_{0} / b\left(1-\mathrm{e}^{(b t)}\right)\right.\right.$, fitted to brown spot disease incidence data in six consecutive growing seasons in relation to conventional and no-tillage systems

\begin{tabular}{|c|c|c|c|c|c|c|}
\hline \multirow{3}{*}{$\begin{array}{l}\text { Season } \\
1997 / 98\end{array}$} & \multicolumn{2}{|c|}{$\begin{array}{l}\text { Initial disease level } y_{0} \\
\text { (std error) }\end{array}$} & \multicolumn{2}{|c|}{$\begin{array}{l}\text { Initial progress rate } r_{0} \\
\text { (std error) }\end{array}$} & \multicolumn{2}{|c|}{$\begin{array}{l}\text { Parameter of rate increase } b \\
\text { (std error) }\end{array}$} \\
\hline & Conventional & No-tillage & Conventional & No-tillage & Conventional & No-tillage \\
\hline & $\begin{array}{l}0.178 \\
(7.00 \mathrm{E}-03)\end{array}$ & $\begin{array}{l}0.1156 * \\
(4.70 \mathrm{E}-03)\end{array}$ & $\begin{array}{l}0.00034 \\
(2.00 \mathrm{E}-04)\end{array}$ & $\begin{array}{l}0.00114 \mathrm{~ns} \\
(3.60 \mathrm{E}-04)\end{array}$ & $\begin{array}{l}0.044 \\
(7.4 \mathrm{E}-3)\end{array}$ & $\begin{array}{l}0.033 \mathrm{~ns} \\
(3.54 \mathrm{E}-3)\end{array}$ \\
\hline 1998/99 & $\begin{array}{l}0.0512 \\
(1.70 \mathrm{E}-03)\end{array}$ & $\begin{array}{l}0.0146 * \\
(7.00 \mathrm{E}-03)\end{array}$ & $\begin{array}{l}0.0252 \\
(1.10 \mathrm{E}-02)\end{array}$ & $\begin{array}{l}0.0334 \mathrm{~ns} \\
(1.32 \mathrm{E}-02)\end{array}$ & $\begin{array}{l}\mathbf{0 . 0 0 0 2} \\
(6.78 \mathrm{E}-3)\end{array}$ & $\begin{array}{l}\mathbf{0 . 0 0 3 4 n s} \\
(5.53 \mathrm{E}-3)\end{array}$ \\
\hline $1999 / 00$ & $\begin{array}{l}0.0962 \\
(5.00 \mathrm{E}-03)\end{array}$ & $\begin{array}{l}0.0411 * \\
(1.20 \mathrm{E}-02)\end{array}$ & $\begin{array}{l}0.0000015 \\
(2.99 \mathrm{E}-06)\end{array}$ & $\begin{array}{l}0.0010 \mathrm{~ns} \\
(1.30 \mathrm{E}-03)\end{array}$ & $\begin{array}{l}0.1131 \\
(2.11 \mathrm{E}-2)\end{array}$ & $\begin{array}{l}0.04435 * \\
(1.58 \mathrm{E}-2)\end{array}$ \\
\hline $2000 / 01$ & $\begin{array}{l}0.09445 \\
(2.20 \mathrm{E}-02)\end{array}$ & $\begin{array}{l}0.0457 \mathrm{~ns} \\
(1.60 \mathrm{E}-02)\end{array}$ & $\begin{array}{l}0.0031 \\
(2.80 \mathrm{E}-03)\end{array}$ & $\begin{array}{l}0.00485 \mathrm{~ns} \\
(4.00 \mathrm{E}-03)\end{array}$ & $\begin{array}{l}0.0285 \\
(1.20 \mathrm{E}-2)\end{array}$ & $\begin{array}{l}0.0275 \mathrm{~ns} \\
(1.40 \mathrm{E}-2)\end{array}$ \\
\hline $2001 / 02$ & $\begin{array}{l}0.1028 \\
(1.22 \mathrm{E}-02)\end{array}$ & $\begin{array}{l}0.0306 * \\
(7.00 \mathrm{E}-03)\end{array}$ & $\begin{array}{l}0.0022 \\
(1.30 \mathrm{E}-03)\end{array}$ & $\begin{array}{l}0.0083 \mathrm{~ns} \\
(3.30 \mathrm{E}-03)\end{array}$ & $\begin{array}{l}0.0262 \\
(6.62 \mathrm{E}-3)\end{array}$ & $\begin{array}{l}0.0168 \mathrm{~ns} \\
(4.21 \mathrm{E}-3)\end{array}$ \\
\hline $2002 / 03$ & $\begin{array}{l}0.0152 \\
(1.50 \mathrm{E}-02)\end{array}$ & $\begin{array}{l}0.0027 \mathrm{~ns} \\
(5.00 \mathrm{E}-03)\end{array}$ & $\begin{array}{l}0.0566 \\
(3.50 \mathrm{E}-03)\end{array}$ & $\begin{array}{l}0.0895 \mathrm{~ns} \\
(7.07 \mathrm{E}-02)\end{array}$ & $\begin{array}{l}-\mathbf{0 . 0 1 1 9} \\
(7.89 \mathrm{E}-3)\end{array}$ & $\begin{array}{l}-\mathbf{0 . 0 1 3 3} \mathbf{~ n s} \\
(9.8 \mathrm{E}-3)\end{array}$ \\
\hline
\end{tabular}

* Indicates significant differences $(p<0.05)$ between the parameter values estimated for disease progress curves from conventional and no-tillage systems; ns indicates no significant differences between parameters

Values for parameter $b$ in bold were not significantly different from 0 by t-test 
reflected in the extremely low initial disease rate which appears to be compensated by a rather high rate increasing parameter $b$ leading to a significant difference in the values of this parameter $b$. In two seasons (1998/99 and 2002/03), the estimated values of the parameter $b$ were not significantly different from 0 in both tillage systems. In these seasons, the disease incidence increased rather early in the season so that the logistic function with constant rate described the disease progression very well and the additional parameter contributed little to the goodness-of-fit, as can be seen by comparing the coefficient of determination of both functions (Figs. 1 and 2). Nevertheless, when the comparison between the tillage systems in these two seasons was carried out with the normal logistic function, the initial disease level $y_{0}$ for conventional tillage was again significantly lower than in the no-tillage system, while the rates $r$ did not differ significantly (not shown).

The disease severity in artificially infected plants at the R1 stage (Fehr et al. 1971) was significantly higher $(p<0.05$, t-test) in old leaflets than those from young leaflets. The average severities $( \pm \mathrm{SD})$ for the four experiments were, respectively, $26.6 \%( \pm 21.9 \%), 5.5 \%( \pm 3.3 \%), 6.3 \%( \pm 5.4 \%)$ and $28.3 \%( \pm 20.8 \%)$ for old leaflets and $7.6 \%( \pm 4.9 \%), 2.0 \%$ $( \pm 2.0 \%), 0.7 \%( \pm 0.5 \%)$ and $5.3 \%( \pm 7.9 \%)$, for new leaflets.

\section{Discussion}

Epidemics of brown spot occurred in all 6 years of the experiment in both soil management treatments, conventional and no-tillage. The initial disease level $\left(y_{0}\right)$ was significantly influenced by the cultivation system and it was higher in conventional tillage than in no-tillage treatment. The higher value of $y_{0}$ in conventional system observed in this work is similar to the observations by Tyler et al. (1983).

The better goodness-of-fit of the logistic model with exponentially increasing rate suggests an increase in the susceptibility of soybean in the course of time, since the speed of disease progress is higher at the end of the epidemic. This change to a higher susceptibility was confirmed in the trials with detached leaves, in which old leaflets showed higher disease severity than young ones.

In southern Brazil, wheat is cultivated in the winter and provides at least $3000 \mathrm{~kg} / \mathrm{ha}$ of residue. At the time of soybean sowing, at least $50 \%$ of this amount of wheat residue is still present on the soil, forming a thick layer of mulch in no-till systems enough to cover the soybean residue that may interfere on the release of Septoria propagules. The amount of straw left after harvesting probably explains the results presented in this paper.

Additionally, Parker et al. (1995) evaluated the importance of rain for the dispersal of Septoria lycopersici spores and quantified the temporal and spatial progress of the disease in field-grown tomatoes. They observed that rain is the primary mechanism for spore dissemination and that disease severity was associated to the amount of rain. Therefore, soil protection with straw from a different crop could delay or inhibit infection. Ristaino et al. (1997) mention the same effect for the pathosystem Phytophthora capsici-pepper. The residues of a previous crop provided an effective barrier to inoculum dispersal.

The no-tillage system used in this study left winter crop residues that covered most of the soil surface, and these residues likely provided an effective barrier to inoculum dispersal in the summer crop. It cannot be disregarded, however, that different pathosystems can behave differently. Several reports determined the effect of conventional soil preparation system in reducing disease intensity, especially with wheat crops. Besides these reports, few papers have demonstrated the beneficial effect of straw on propagule dispersion. Only with an efficient and economical double cropping system can this be achieved.

Acknowledgments We thank Dr. Regina M.V.B.C. Leite and Dr. Norman Neumaier for their helpful comments. We also thank Nilson V. de Souza and Luis C. Benato for technical assistance. A.M.R. Almeida gratefully acknowledges financial support by EMBRAPA and Conselho Nacional de Desenvolvimento Científico e Tecnológico (CNPq).

\section{References}

Almeida AMR (1980) Efeito da inoculação de Septoria glycines Hemmi em plantas de soja em quatro estádios de desenvolvimento. Fitopatol Bras 5:163-168

Almeida AMR (2001) Observação de resistência parcial a Septoria glycines em soja. Fitopatol Bras 26:214-216

Almeida AMR (2003) Doenças de soja nos sistemas de semeadura direta e convencional. Fitopatol Bras 28:40-42

Almeida AMR, Ferreira LP, Torres E, Gaudêncio CA, Farias JRB (1999) Severidade de doenças foliares e radiculares em soja cultivada nos sistemas de semeadura direta e convencional, com rotação ou sucessão. I Congresso Brasileiro de Soja, Abstracts... Embrapa Soja, Londrina. p 442

Almeida AMR, Ferreira LP, Yorinori JT, Silva JFV, Henning AA, Godoy CV, Costamilan LM, Meyer MC (2005) Doenças da Soja. In: Kimati H, Amorim L, Rezende JAM, Bergamin Filho A (eds) Manual de Fitopatologia 2. Doenças das Plantas Cultivadas. Ceres, São Paulo, pp 569-588

Bergamin Filho A, Amorim L, Laranjeira FF, Berger RD, Hau B (1998) Análise temporal do amarelecimento fatal do dendezeiro como ferramenta para elucidar sua etiologia. Fitopatol Bras 23:391-396

Campbell CL, Madden LV (1990) Introduction to plant disease epidemiology. Wiley, New York

Fehr WR, Caviness CE, Burmood DT, Pennington JS (1971) Stage of development descriptions for soybeans, Glycine $\max (\mathrm{L}$.) Merrill. Crop Sci 11:929-931

James CA (1971) Manual of assessment keys for plant diseases. APS Press, St. Paul

Madden LV, Hughes G, Bosch FVD (2007) The study of plant disease epidemics. APS Press, St. Paul 
Parker SK, Gleason ML, Nutter FW (1995) Influence of rain events on spatial distribution of Septoria leaf spot of tomato. Plant Dis 79:148152

Ristaino JB, Parra G, Campbell CL (1997) Suppression of Phytophthora blight in bell pepper by a no-till wheat cover crop. Phytopathology 87:242-249

Schuh W, Adamowicz A (1993) Influence of assessment time and modeling approach on the relationship between temperature-leaf wetness periods and disease parameters of Septoria glycines on soybean. Phytopathology 83:941-948
Tyler DD, Overton JR, Chambers AY (1983) Tillage effects on soil properties, diseases, cyst nematodes and soybean yields. J Soil Water Conserv 38:374-376

Wrather JA, Anderson TR, Arsyad DM, Ploper LD, Porta-Puglia A, Ram HH, Yorinori JT (1997) Soybean disease losses estimates for the top 10 soybean producing countries in 1994. Plant Dis 78:107-110

Yorinori JT (1994) Fungal Diseases. In: Tropical soybean: improvement and production. FAO Plant Production and Protection Series no. 27. FAO/Embrapa Soja, Londrina. pp 37-60 